\title{
Cultivation of Chlorella pyrenoidosa as a raw material for the production of biofuels in palm oil mill effluent medium with the addition of urea and triple super phosphate
}

\author{
Shinta Elystia ${ }^{1^{(\mathbb{D}}}$, Sri Rezeki Muria ${ }^{2^{\mathbb{D}}}$, Herta Furaida Erlangga $^{\mathbb{1}}$ \\ ${ }^{1}$ Department of Environmental Engineering, Faculty of Engineering, Riau University, Kampus Bina Widya, Pekanbaru, Riau 28293, \\ Indonesia \\ ${ }^{2}$ Department of Chemical Engineering, Faculty of Engineering, Riau University, Kampus Bina Widya, Pekanbaru, Riau 28293, Indonesia
}

\begin{abstract}
Background: The utilization of microalgae as a renewable energy is an important aspect in solving shortage of future oil reserve in 15 years. One of the renewable energy sources is microalgae biodiesel. Palm oil mill effluent (POME) is a wastewater that has a high content of organic materials. These organic materials can be used as growth nutrients for microalgae. Chlorella pyrenoidosa is one of the most potential microalgae used as a raw material for the production of biodiesel since it contains lipids (8\%-35\%).

Methods: Chlorella pyrenoidosa was cultured on the POME medium with concentrations of $0 \%, 25 \%$, $50 \%, 75 \%$, and $100 \% \mathrm{v}$ with addition of synthetic nutrients (urea: TSP) at the ratios of $2: 1 ; 1: 2 ; 0.5: 1$ in a $500 \mathrm{~mL}$ Erlenmeyer flask, at pH 6-8, aeration using aquarium pumps, and using LED lights (3000 lux). Results: It was revealed that at POME concentration of $25 \%$ and with addition of urea: TSP at a ratio of 2:1, the optimum specific growth rate (0.306/day) with the highest number of cells was $3.530 \times 10^{7}$ cells $/ \mathrm{mL}$ and the highest lipid content was $36 \%$ of its dry weight. The removal efficiency of POME could be obtained from the removal efficiency of chemical oxygen demand (COD), total nitrogen, and orthophosphate $\left(\mathrm{P}^{-} \mathrm{PO}_{4}\right)$, which was $70,90.42$, and $81.12 \%$, respectively.

Conclusion: According to the results, under appropriate culture conditions, C. pyrenoidosa can produce lipids with good use of nutrients contained in the POME medium.

Keywords: Chlorella pyrenoidosa, POME, Lipid, Urea: TSP

Citation: Elystia S, Muria SR, Erlangga HF. Cultivation of Chlorella pyrenoidosa as a raw material for the production of biofuels in palm oil mill effluent medium with the addition of urea and triple super phosphate. Environmental Health Engineering and Management Journal 2020; 7(1): 1-6. doi: 10.34172/ EHEM.2020.01.
\end{abstract}

Article History:

Received: 7 August 2019

Accepted: 10 December 2019

ePublished: 13 January 2020

\section{Introduction}

Microalgae have recently become a worldwide concern as a new raw material for the biofuel production (1). It is an organism that is considered as an ideal and potential raw material for bioenergy production (2). Microalgae is a photosynthetic microorganism that has the ability to use sunlight and carbon dioxide to produce algal biomass (3). It is a potential raw material that can fulfill the global demand for transportation fuels in the future, since microalgae can be produced in a short time and can produce oil 10 times more than oil derived from food crops (4).

Biofuels production from microalgae biomass can provide a pollution-free and environmentally friendly energy source (5). The idea of using microalgae as a source of fuel has become a serious discussion due to the increase of fuel prices and environmental problems related to global warming due to burning fossil fuels (6). The increase in fuel prices is due to the increasing dependence of the society on fuel, which causes a reduction in oil reserves (7). Recently, biodiesel (green fuel) as a renewable and nontoxic energy which produces low amounts of pollution has been proposed as a replacement for fossil fuels. The use of this fuel leads to a decrease in the harmful emissions of carbon monoxide, hydrocarbons, and particulate matter, as well as the elimination of SOx emissions, and as a result, a decrease in the negative effects of greenhouse gases (8). Microalgae can produce high enough lipids $( \pm 65 \%$ in its dry weight) to be converted into biodiesel (9). Microalgae are chosen because of its ability to grow quickly, live in 
freshwater, seawater, and wastewater, while it does not require a large area for its production activities. Besides, it can absorb carbon dioxide, so that it can reduce the negative effects of greenhouse gases (10). Economically, microalgae are chosen because of its considerable availability and low production costs $(11,12)$. One of the potential microalgae that can be developed into bioenergy raw material is Chlorella pyrenoidosa.

Chlorella pyrenoidosa is a unicellular green algae that lives in freshwater, seawater, and wet areas. Moreover, C. pyrenoidosa can grow and develop very quickly (13). In Riau, especially in PT Perkebunan Nusantara (PTPN V) Riau province, C. pyrenoidosa grows abundantly in sewage treatment ponds. C. pyrenoidosa has a lipid content ranging from $8 \%-35 \%$ (14). The growth rate, cell density, and lipid content of the microalgae are essential parameters contributing to lipid production (8). To obtain the high amount of biomass with optimum lipid content, it is necessary to do the cultivation process. In this study, C. pyrenoidosa was cultivated using a medium of palm oil mill effluent (POME) containing organic materials, which can be used as a carbon source for the cultivation media $(15,16)$. Cultivation of algae in the POME waste is an effective and efficient alternative. POME is a highstrength effluent rich in minerals, such as $\mathrm{N}, \mathrm{P}, \mathrm{K}$, and other minerals suitable for growing media for algae. By utilizing POME for microalgae cultivation, palm oil mills can apply the principle of reduction because there will be a reduction in the volume of waste. It is because the treated POME contains nutrients with a mass ratio of $\mathrm{C}: \mathrm{N}$ : $\mathrm{P}$ (34: 5: 1) (17), whereas microalgae requires nutrients that are large enough with the mass ratio of $\mathrm{C}$ : $\mathrm{N}$ : P (56: 9: 1) (18). Studies have shown that the quality and quantity of the microalgae lipid content can be changed as a result of changes in growth conditions (temperature, light intensity) or medium composition (nitrogen, phosphate, and iron concentration) (19). Some studies are already done on the methods of microalgae extraction from POME medium by centrifugation using Chlorella (20). In recent studies, only microalgae Chlorella sp or Chlorella vulgaris were used to investigate the effect of medium cultivation with a variation in the growth conditions (20). The purpose of this study was to fulfill the nutritional needs of microalgae for lipid production extracted from microalgae, as well as the utilization of algae blooms in sewage treatment ponds in PTPN V, Riau province. So, it is necessary to manipulate the availability of nutrients

\section{Materials and Methods}

The medium used for the cultivation process was POME from PTPN V Riau province. The additional nutrients were added in the form of urea and TSP. C. pyrenoidosa was obtained from the cultivation using a chamber coated with aluminum foil, which serves to keep the resulting light intensity quantized so that the microalgae in the Erlenmeyer flask get maximum light. C. pyrenoidosa was collected from BBPBAP Jepara, which was cultivated using Bold Basal Medium (BBM).

Calculation of cell density and specific growth rate Microalgae cell number was calculated using a thomacytometer during the data collection period of 0,1 , $3,5,7,9,11$, and 13 days. The microalgae cell density was calculated using the following formula:

$\mathrm{N}=\mathrm{n} \times 10^{4}$

Where $N$ is $C$. pyrenoidosa cell density (cell/mL) and $n$ is the total number of cells calculated for each sample (cells). The specific growth rate of microalgae was calculated using the following formula:

$\mu_{\max }=\frac{\ln (x i)-\ln (x o)}{(t i-t o)}$

Where $X_{o}$ is microalgae cell density at the beginning of cultivation, $X i$ is microalgae cell density at the end of cultivation, and ti-to is duration of cultivation time.

\section{Calculation of lipid extraction}

Lipid extraction was carried out by the Bligh and Dyer method (21). The lipids were extracted with chloroformmethanol solution $(2: 1, \mathrm{v} / \mathrm{v})$, and then separated into a liquid layer of chloroform and methanol. Methanol and water were added to produce the final solvent from the mixture of chloroform: methanol: water (1: 1: 0.9). The chloroform layer was washed with 1 drop of $\mathrm{HCl} 6 \mathrm{~N}$ solution and evaporated to dry (22). The total lipids were determined gravimetrically (23).

$\%$ Total lipid $=\frac{L w}{B w} \times 100$

Where $L w$ is lipid weight $(\mathrm{g})$ and $B w$ is microalgae biomass weight $(\mathrm{g})$.

Calculation of removal efficiency of COD, total nitrogen, and orthophosphate $\left(\mathrm{P}-\mathrm{PO}_{4}\right)$

To calculate the percentage of removal efficiency of chemical oxygen demand (COD), TN, and $\mathrm{P}_{-} \mathrm{PO}_{4}$, the following equation was used:

Efficiency $(\%)=\left[\left(\frac{\text { Cin }- \text { Cef }}{\text { Cin }}\right)\right] x 100 \%$

Where Cin is influent concentration $(\mathrm{mg} / \mathrm{L})$ and Cef is effluent concentration (mg/L) (24).

Results

During the cultivation periods, microalgae were observed for 13 days with sampling time on days $0,1,3,5,7,9,11$, and 13 using a thomacytometer with the variables used including POME concentration and nutrients ratio of urea: TSP. 
Cell density and specific growth rate of Chlorella pyrenoidosa

Cell density and specific growth rate of $C$. pyrenoidosa were obtained in a medium containing POME of $25 \% \mathrm{v}$ with the addition of urea: TSP $(2: 1)$, which were equal to $3530 \times 10^{4}$ cells/mL (Figure 1A) and 0.530/day, respectively (Figure 2). As shown in Figure 1, the higher the medium POME concentration, the lower the microalgae cell density in the cultivation process.

As shown in Figure 1, the cell density of each treatment was different. At a concentration of $0 \%$ (control), the growth rate of $C$. pyrenoidosa increased rapidly followed by a $25 \%$ POME concentration, while at a concentration of $50 \%, 75 \%$, and $100 \%$, the growth rate of C. pyrenoidosa decreased. The highest cell density values were obtained in a medium containing 25\% POME with the addition of urea:TSP (2:1), which was equal to $3530 \times 10^{4}$ cells/ $\mathrm{mL}$ (Figure 1A). This value was obtained on the $9^{\text {th }}$ day
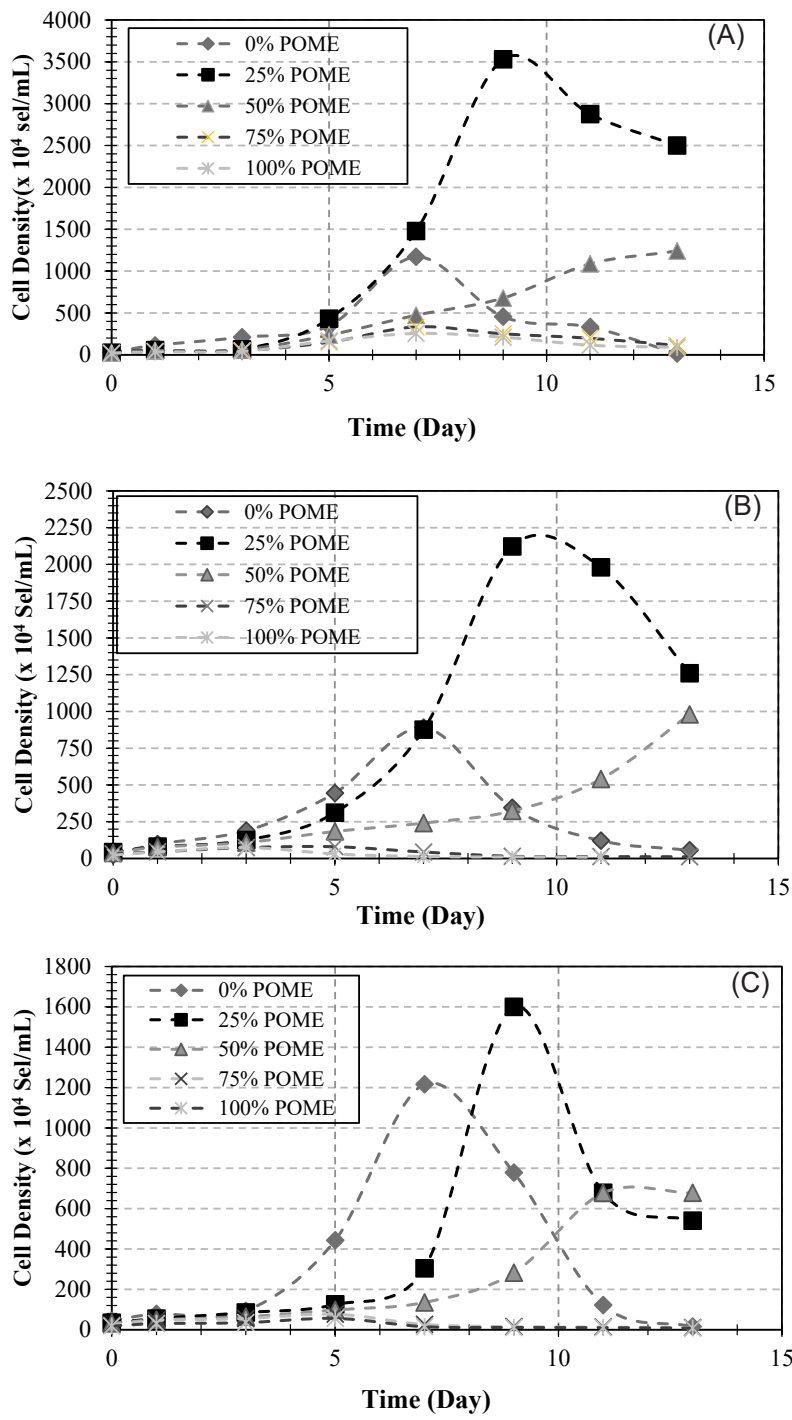

Figure 1. Cell density of $C$. pyrenoidosa with a variation in the nutrients ratio of urea: TSP. (A) 2:1, (B) 1:2, (C) 0.5:1 of cultivation, which was in the exponential phase. The increase of cell density could be seen in the magnitude of the average growth rate of cell in each phase. The growth rate of microalgae in each treatment can be seen in the specific growth rate graph in Figure 2 .

As shown in Figure 2, the specific growth rate of each treatment was different. The highest growth rate $(0.530 /$ day) was obtained in the medium of $25 \%$ POME and with the addition of nutrients with a ratio of $2: 1$, while the lowest one (0.306/day) was obtained at 100\% POME concentration.

\section{Lipid production}

Lipid content was strongly influenced by several factors, such as medium composition, light intensity, nutrition, and $\mathrm{pH}$ (25). Changes in these factors caused differences in lipid content in cells. In this study, the highest lipid content of C. pyrenoidosa was $36 \%$ (dry weight) on the $11^{\text {th }}$ day of cultivation. This value was obtained in the variation of $25 \% \mathrm{v}$ POME medium and with the addition of urea: TSP (2:1). The lipid content of C. pyrenoidosa can be seen in Figure 3.

As shown in Figure 3, the highest lipid content was found after the addition of urea: TSP $(2: 1)$. It can be seen that the addition of nutrients in the form of urea and TSP resulted in the increase of lipid content, while nitrogen and phosphate derived from urea and TSP had important functions in the process of cell metabolism, including chlorophyll synthesis, because high chlorophyll content would cause the photosynthesis process to run well (26). The relationship between cell density and lipid content can be seen in Figure 4.

Allowance for COD, nitrogen, and orthophosphate In the process of cultivation carried out for 13 days, the removal efficiency of COD, nitrogen, and phosphate were obtained to be $90.42,70$, and $81.12 \%$, respectively, in the medium of $25 \%$ POME with the addition of urea: TSP (2:1). Microalgae can reduce the pollutant compounds found in POME, where organic compounds can also be utilized by microalgae as a source of energy and carbon

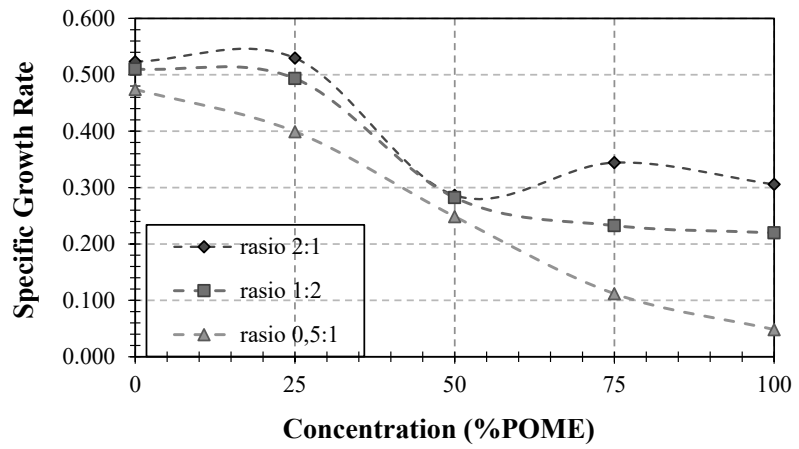

Figure 2. The specific growth rate of $C$. pyrenoidosa with a variation in the ratio of urea:TSP. 


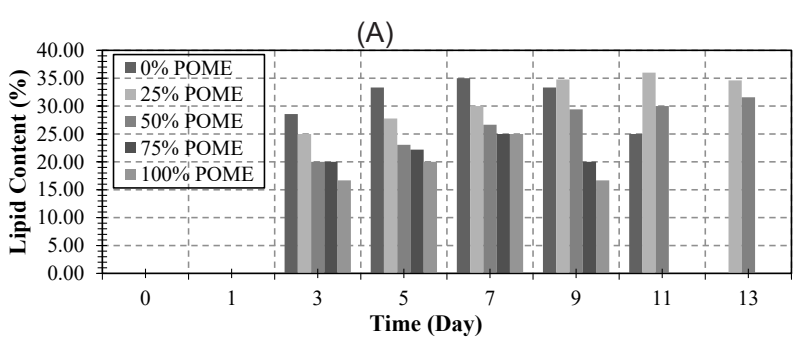

(B)

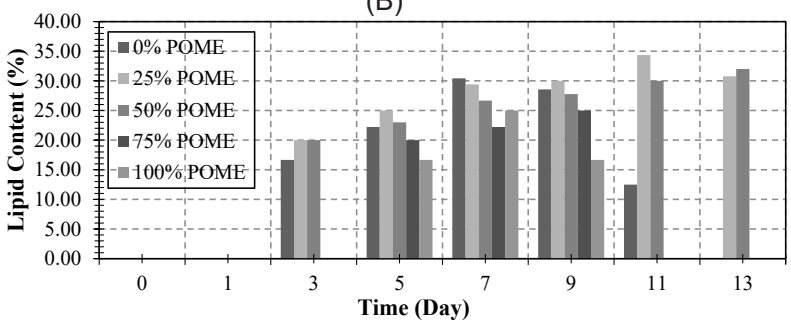

(C)

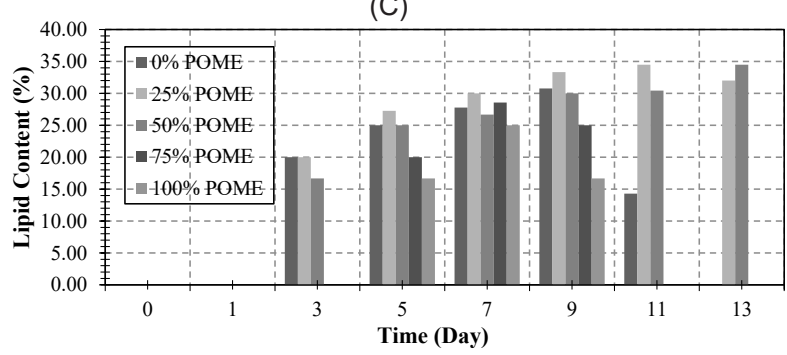

Figure 3. The relationship between waste concentrations and addition of nutrients with lipid content. (A) 2:1, (B) 1:2, (C) 0.5:1.

resources, which reduces the need for the additional nutrients for microalgae. Nutrients play an important role in the microalgae growth as a source of energy to produce biomass (26).

\section{Discussion}

The results show that C. pyrenoidosa showed high specific growth rate and lipid content in some conditions. At high concentrations of POME, microalgae were not able to digest nutrients in the excess POME, so that it could reduce the digestibility and there was the possible production of toxic metabolites (27). At $0 \%$ concentration (control), the growth rate of C. pyrenoidosa was fast followed at $25 \%$ concentration, while at concentrations of 50,75, and $100 \%$, the growth of C. pyrenoidosa decreased. High POME concentrations can be a shortened phase of algae cell adaptation and takes a long time to reach the stationary phase, so produce in lower biomass due to the duration of the adaptation phase (20). The highest cell density was obtained to be $3,530 \times 10^{4} \mathrm{cell} / \mathrm{mL}$ in the medium of $25 \%$ POME with the addition of urea: TSP (2:1). This value was obtained on the 9th day of cultivation in the exponential phase. In the exponential phase, the cell division started and marked by rising growth rate so that the population density increased (28). The addition of nutrients with a ratio of 2:1 produced the highest cell density in almost all variations of the medium concentration. This was because

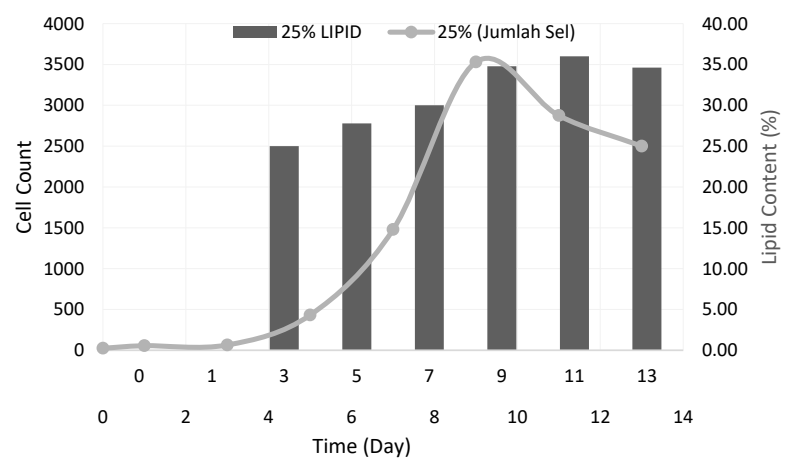

Figure 4. The relationship between microalgae cell density and lipid content over time with optimum variables.

the addition of nutrients at a ratio of 2:1 contained suitable nutrients for the growth of C. pyrenoidosa. Consequently, it resulted in a high increase in cell growth rate as well. This result is consistent with the results reported by Lee (29), who found that in addition to low cell density, microalgae lacking nitrogen and phosphate $(0 \mathrm{ppm})$ also had a less green color compared to those with higher concentrations of nitrogen and other phosphates. At the beginning of the phase (day 0 to day 5 ), microalgae cells would accumulate large amounts of chlorophyll molecules when nitrogen and phosphate sources were still abundant, then, when the extracellular nitrogen source completely consumed, the cells would start to use chlorophyll as a source of intracellular nitrogen, which resulted in a reduction in chlorophyll concentration in the cell. The increase of cell density could be seen from the magnitude of the average growth rate of cell in each phase (30). When urea and TSP were added to the POME medium, microalgae growth would become faster, but the lipid content at the beginning of cultivation tended to be lower. This happened because, in the early phases of growth, the microalgae synthesized more proteins for cell growth and propagation (31). When the microalgae reached the stationary phase, the lipid content in the microalgae would increase. This happened because in this phase, the nutrient content in the culture media started to run out and more accumulated of microalgae through photosynthesis resulted in the production of lipids (32). In the process of cultivation carried out for 13 days, removal efficiency of COD, nitrogen, and phosphate was obtained to be $90.42,70$, and $81.12 \%$, respectively, in the medium of $25 \%$ POME with the addition of urea: TSP $(2: 1)$. Microalgae can reduce the pollutant compounds found in POME, where organic compounds can also be utilized by microalgae as a source of energy and carbon resources, which reduces the need for the additional nutrients for microalgae (33). Nutrients plays an important role in the microalgae growth as a source of energy to produce biomass. Microalgae cell growth is inversely proportional to the content of nutritional parameters in the POME. In other words, by increasing the microalgae amount, the COD, nitrogen, and phosphate decrease. This is because 
microalgae cells grow by utilizing organic ingredients in the waste as nutrients for growth (25).

\section{Conclusion}

This study examined the growth of C. pyrenoidosa with a variation in the POME concentration and addition of urea and TSP. At 25\% POME concentration and with addition of urea: TSP (2:1), a better medium for the growth of microalgae with the highest number of cells $(3.530 \times$ 107 cells $/ \mathrm{mL}$ ) and the highest lipid content of $36 \%$ in dry weight was obtained. The removal efficiency of COD, nitrogen, and orthophosphate ( $\left.\mathrm{P}-\mathrm{PO}_{4}\right)$ were $90.42 \%, 70 \%$, and $81.12 \%$, respectively.

\section{Acknowledgements}

The authors wish to express their gratitude to the Research Laboratory of Chemical Engineering, Faculty of Engineering and the algal Research Center, Riau University for their support in this research.

\section{Ethical issues}

The authors hereby certify that all data collected during the study are as stated in the manuscript, and no data from the study has been or will be published separated elsewhere.

\section{Competing interests}

The authors declare that they have no conflict of interests.

\section{Author's contributions}

The authors contributed and were involved in the problem suggestion, experiments design, data collection, and manuscript approval.

\section{References}

1. Schenk PM, Thomas-Hall SR, Stephens E, Marx UC, Mussgnug JH, Posten C, et al. Second generation biofuels: high-efficiency microalgae for biodiesel production. Bioenergy Res 2008; 1(1): 20-43. doi: 10.1007/s12155-0089008-8.

2. Junaidi AB, Zulfikurrahman, Abdullah, Gunawan. Ekstraksi lipid dari biomassa synechococcus sp. dengan metode osmotic shock. Sains dan Terapan Kimia 2014; 8(2): 94-102. doi: 10.20527/jstk.v8i2.2138. [In Indonesian].

3. González MG. Microalgae Biotechnology. [cited 2019 Jun 17] Available from: https://www.ibvf.us-csic.es/en/ microalgae-biotechnology.

4. Costa JV, de Morais MG. The role of biochemical engineering in the production of biofuels from microalgae. Bioresour Technol 2011; 102(1): 2-9. doi: 10.1016/j. biortech.2010.06.014.

5. Barnwal BK, Sharma MP. Prospects of biodiesel production from vegetable oils in India. Renew Sustain Energy Rev 2005; 9(4): 363-78. doi: 10.1016/j.rser.2004.05.007.

6. Gavrilescu M, Chisti Y. Biotechnology-a sustainable alternative for chemical industry. Biotechnol Adv 2005; 23(7-8): 471-99. doi: 10.1016/j.biotechadv.2005.03.004.
7. Zaldivar J, Nielsen J, Olsson L. Fuel ethanol production from lignocellulose: a challenge for metabolic engineering and process integration. Appl Microbiol Biotechnol 2001; 56(1-2): 17-34. doi: 10.1007/s002530100624.

8. Malakootian M, Hatami B, Dowlatshahi S, Rajabizadeh A. Growth and lipid accumulation in response to different cultivation temperatures in Nannochloropsis oculata for biodiesel production. Environ Health Eng Manag 2016; 3(1): 29-34.

9. Assadad L, Utomo BS, Sari RN. Pemanfaatan mikroalga sebagai bahan baku bioetanol. Squalen 2010; 5(2):51-8. [In Indonesian].

10. Widjaja A, Chien CC, Ju YH. Study of increasing lipid production from fresh water microalgae Chlorella vulgaris. J Taiwan Inst Chem Eng 2009; 40(1): 13-20. doi: 10.1016/j. jtice.2008.07.007.

11. Sharif Hossain AB, Salleh A, Boyce AN, Chowdhurry P, Naqiuddin M. Biodiesel fuel production from algae as renewable energy. Am J Biochem Biotechnol 2008; 4(3): 250-4. doi: 10.3844/ajbbsp. 2008.250.254.

12. Harun R, Danquah MK, Forde GM. Microalgal biomass as a fermentation feedstock for bioethanol production. J Chem Technol Biotechnol 2010; 85(2): 199-203. doi: $10.1002 /$ jctb. 2287.

13. Hadiyanto, Azim M. Mikroalga: Sumber Pangan \& Energi Masa Depan. Semarang: UPT UNDIP Press; 2012. [In Indonesian].

14. John RP, Anisha GS, Nampoothiri KM, Pandey A. Micro and macroalgal biomass: a renewable source for bioethanol. Bioresour Technol 2011; 102(1): 186-93. doi: 10.1016/j. biortech.2010.06.139.

15. Clarens AF, Resurreccion EP, White MA, Colosi LM. Environmental life cycle comparison of algae to other bioenergy feedstocks. Environ Sci Technol 2010; 44(5): 1813-9. doi: 10.1021/es902838n.

16. Lam MK, Lee KT. Renewable and sustainable bioenergies production from palm oil mill effluent (POME): winwin strategies toward better environmental protection. Biotechnol Adv 2011; 29(1): 124-41. doi: 10.1016/j. biotechadv.2010.10.001.

17. Sari FY, Suryajaya IM, Hadiyanto H. mikroalga spirulina platensis dalam media pome dengan variasi konsentrasi pome dan komposisi jumlah nutrien. Jurnal Teknologi Kimia dan Industri 2012; 1(1): 487-94. [In Indonesian].

18. Costa JA, Colla LM, Duarte Filho P. Spirulina platensis growth in open raceway ponds using fresh water supplemented with carbon, nitrogen and metal ions. Z Naturforsch C J Biosci 2003; 58(1-2): 76-80.

19. Malakootian M, Hatami B, Dowlatshahi S, Rajabizadeh A. Optimization of culture media for lipid production by Nannochloropsis oculata for Biodiesel production. Environ Health Eng Manag 2015; 2(3): 141-7.

20. Nur MM, Hadiyanto H. Lipid extraction of microalga chlorella sp. cultivated in Palm Oil Mill Effluent (POME) medium. World Appl Sci J 2014; 31(5): 959-67. doi: 10.5829/ idosi.wasj.2014.31.05.2006. [In Indonesian].

21. Bligh EG, Dyer WJ. A rapid method of total lipid extraction and purification. Can J Biochem Physiol 1959; 37(8): 911-7. doi: 10.1139/059-099.

22. Putri EV, Md Din MF, Ahmed Z, Jamaluddin H, Chelliapan 
S. Investigation of Microalgae for High Lipid Content using Palm Oil Mill Effluent (POME) as Carbon Source. Singapore: IACSIT Press; 2011.

23. Yoo C, Jun SY, Lee JY, Ahn CY, Oh HM. Selection of microalgae for lipid production under high levels carbon dioxide. Bioresour Technol 2010; 101(1): S71-4. doi: 10.1016/j.biortech.2009.03.030.

24. Wiyantoko B, Kurniawaty P, Purbaningtias TE. Pengujian Nitrogen Total, Kandungan Air dan Cemaran Logam Timbal pada Pupuk Anorganik Nitrogen Phospor Kalium (NPK) Padat. Jurnal Sains dan Teknologi 2017; 6(1): 51-60. doi: 10.23887/jst-undiksha.v6i1.9439. [Indonesian].

25. Kamyab H, Md Din MF, Lee CT, Keyvanfar A, Shafaghat A, Abd Majid MZ, et al. Lipid production by microalgae Chlorella pyrenoidosa cultivated in palm oil mill effluent (POME) using hybrid photo bioreactor (HPBR). Desalin Water Treat 2014; 55(13): 3737-49. doi: 10.1080/19443994.2014.957943.

26. Istirokhatun $\mathrm{T}$, Aulia M, Utomo S. Potensi Chlorella Sp. untuk Menyisihkan COD dan Nitrat dalam Limbah Cair Tahu. J Presipitasi 2017; 14(2): 88-96. doi: 10.14710/ presipitasi.v14i2.88-96. [In Indonesian].

27. Faradilla A, Juwita AR. Pemanfaatan Air Limbah Pabrik Pupuk Kadar Amonia Tinggi sebagai Media Kultur
Mikroalga untuk Perolehan Sumber Minyak Nabati sebagai Bahan Bakar biodiesel. [cited May 2019 17] Available from: http://eprints.undip.ac.id/36783/1/83.Artikel_Skripsi_ Pemanfaatan_Air_Limbah.pdf. [In Indonesian].

28. Kawaroe M, Prartono T, Sunuddin A, Wulansari D, Augustine D. Mikroalga Potensi dan Pemanfaatannya Untuk Produksi Bio Bahan Bakar. Bogor: IPB Press; 2010. [In Indonesian].

29. Lee RE. Phycology. 4th ed. New York: Cambridge University Press; 2008.

30. Handajani H. Pemanfaatan limbah cair tahu sebagai pupuk alternatif pada kultur mikroalga Spirullinasp. Jurnal Protein 2006; 13(2): 188-93. [In Indonesian].

31. Bellou S, Aggelis G. Biochemical activities in Chlorella sp. and Nannochloropsis salina during lipid and sugar synthesis in a lab-scale open pond simulating reactor. J Biotechnol 2012; 164(2): 318-29. doi: 10.1016/j.jbiotec.2013.01.010.

32. Liu ZY, Wang GC, Zhou BC. Effect of iron on growth and lipid accumulation in Chlorella vulgaris. Bioresour Technol 2008; 99(11): 4717-22. doi: 10.1016/j.biortech.2007.09.073.

33. Xin L, Hu HY, Ke G, Jia Y. Growth and nutrient removal properties of a freshwater microalga Scenedesmus sp. LX1 under different kinds of nitrogen sources. Ecol Eng 2010; 36(4): 379-81. doi: 10.1016/j.ecoleng.2009.11.003. 